\title{
Estimating Willingness to Pay to Protect Acequia Irrigation and Culture: Lessons from San Miguel County, NM
}

\author{
Nejem Raheem \\ Emerson College, USA \\ Nejem_raheem@emerson.edu
}

\begin{abstract}
Traditional gravity fed irrigation systems in Hispano communities in New Mexico, USA, are referred to as acequias. Water scarcity is currently motivating negotiations between acequias and municipalities over sharing agreements. Research on willingness to pay to protect and maintain acequias is still scarce. These valuation data could be helpful to improve the quality of water resources decision making and therefore rural development strategies in this region, which is relatively poor compared to the US average. Data from an open-ended CVM survey are used to examine WTP for a program designed to strengthen and perpetuate irrigation and culture on the acequias of El Río de las Gallinas, in rural northeastern New Mexico. Results indicate that the community supports the program in general, with higher levels of support among rural residents and Anglos.
\end{abstract}

Keywords: Contingent Valuation Method, acequia irrigation, New Mexico, benefit cost analysis.

\section{Introduction}

The history of the US West is partly a history of water conflict (Wilkinson, 1992; Reisner, 1986; Phillips et al., 2011).With increases in population and economic growth ${ }^{4}$, that conflict seems bound to intensify. In northern New Mexico traditional irrigation ditches known as acequias are in the middle of this conflict.

Traditional, common-property irrigation ditches are often called acequias de común in New Mexico (Rodriguez, 2006; Rivera, 1998, 2006). This term is usually shortened to acequias. Centuries-old, acequias descend from a shared Roman, Islamic, Spanish, and Native American heritage. The name derives from the Arabic "as-sakiya," or "the water-bearer (Peña, 2003)." Spanish settlers inherited Roman and Moorish irrigation systems in southern Spain (Simmons, 1972; Phillips et al., 2011), which technology and law they brought to the New World. These systems dovetailed with and changed through contact with indigenous irrigation systems in the upper Rio Grande valley, or Rio Arriba (Rivera, 2006; Simmons, 1972).

The term acequia itself carries a sort of weight in New Mexico, as not all irrigation ditches are thus called. In certain regions, for instance the Middle Rio Grande Conservancy District, some irrigation ditches are simply called ditches, while others have the status of acequia. Typically the term acequia applies to a community ditch, where there is some extent of communally owned and maintained conveyance or ditchbank easement for access to the ditch. Additionally, the traditional Spanish term for someone who irrigates from an acequia is parciante, which is not immediately interchangeable with the term irrigator. A parciante is really a term to designate a position within a community; one who partakes in the benefits of irrigation but also contrib- 
utes to its upkeep, and the term has come to signify a specific relationship to common pool resource management within at least a somewhat traditional management context (Rodriguez 2006; Rivera, 1998). Additionally, it is used almost entirely in traditionally Hispano communities. Indigenous irrigators would not necessarily call themselves parciantes, surely as the term hardly exists outside New Mexico in the US, with the exception of parts of southern Colorado. Some will interchangeably use the terms irrigators or parciantes, just as sometimes people will alternately use acequia or ditch. With a few exceptions, this paper refers to acequias and parciantes throughout. This is in part to distinguish them from other, non-communal or commercial irrigation operations, and also to use their own terminology for themselves. It is common for both Hispano and non-Hispano irrigators on an acequia to call themselves parciantes. As with any traditional, culturally embedded natural resource management system, some of the terminology is highly local, and its use provides a more accurate picture of the system than would more generic terms.

Acequias have supplied water to crops and villages in a high altitude region with scarce and variable water supplies (Thomson, 2012; Gutzler, 2012) for centuries (Hutchins, 1928; Rodriguez, 2006). With changes in water law (Hall, 2012; Philips et al., 2011; Rivera, 1998; Rodriguez, 2006; NMAA, 2005; Keleher, 1929), ethnic composition, and property rights regimes, the acequias are seen as fighting a battle against what could be called "modernization" or integration into an unfamiliar culture (Rodriguez, 2006; Rivera, 1998; Peña, 2003).

In New Mexico, water sales can be legally contested for several reasons (Nunn et al., 1991; Colby, 1995). One basis for contest is if the transfer is deemed to violate the "public welfare" of the state (NM Statute72-5-231; Bokum, 1996; Rivera, 1996; Brown et al., 1996). New Mexico water law allows acequia associations to prohibit members from selling their rights if such a sale is deemed to be harmful to the functioning of the acequia (NM Statutes 73-2-21.E, 73-3.4.1, 72-5-24.1; NMAA, 2005). Bokum's draft framework for a public welfare regulation suggests that the New Mexico Office of the State Engineer (NMOSE) request a benefit-cost analysis for certain water rights sales. Including costs or benefits only in terms of agricultural sales will likely underestimate the true value of water in acequias, which contribute a suite of ecosystem services such as groundwater recharge and various cultural attributes. Despite this, the state of New Mexico has neither a clear definition of public welfare nor any pertinent legislation on the topic as it relates to water. This is not for lack of attempts to clarify public welfare (Rivera, 1996, 1998; Bokum 1996).

Despite discussion about the public welfare values of acequia irrigation in the state of New Mexico (NM Statute72-5-23; Bokum, 1996; Rivera, 1998; Fleming et al., 2001; Peña, 2003), there is still relatively little research on willingness to pay to protect and maintain these systems (Archambault \& Ulibarri, 2007). In this paper I report results from an open-ended (OE) contingent valuation method (CVM) survey to model the demand for acequia irrigation and culture (Rivera, 1998) in New Mexico (NM), USA. Specifically, I examine the willingness to pay (WTP) of residents of San Miguel County, in northeastern NM, for a training program designed to strengthen and perpetuate irrigation and culture on the acequias of El Río de las Gallinas.

Ascertaining demand for acequia irrigation and culture as part of a broader effort to uncover preferences for water use and culture in New Mexico can be useful for prioritizing uses. Clear dollar values for the growth of industry or even municipalities can overshadow traditional uses which have less obvious worth. These values could be included in a formal cost benefit analysis of water transfers in the basin or region. 


\subsection{Background on Acequias}

Acequia-irrigated farms play an ever-smaller role in direct subsistence in the region (Rodriguez, 2006). Between 1997 and 2002, the number of farms in San Miguel County, the study area, decreased by $28 \%$, while acres of farmed land decreased by $18 \%$ (NASS 2002a). Land use patterns in Alcalde, NM, show a 553\% increase in residential use between 1962 and 2003, and a decrease in many crops, with orchard crop area decreasing by $69 \%$, for example, and only pasture area increasing, by 47\% (Ortiz et al., 2007). This does not, however, mean that they are less important; in fact they generate many benefits. Rodriguez (2006) Rivera (1998), and Pena (2003), among others, describe their contributions to cultural integrity, mutuality, the continuation of Hispano religious traditions, and their potential to suggest alternative water management paradigms and their contributions of important hydrological ecosystem services (Fernald \& Guldan, 2006; Fernald et al., 2007; MEA, 2005).

Acequias, with their particular history of water rights and communal management structure, remain relatively intact in northern New Mexico. In the acequia system, water is historically owned and distributed collectively (Simmons, 1972; Hutchins, 1928). Currently all water rights are private. The ditch association does not own water rights, only the individual irrigators. While the systems are usually governed by a fairly strict rotation scheme based on either acreage irrigated or simply on an even division of time, there is also a way that irrigators can share water during scarce times. On some ditches, each parciante is given an equal number of hours out of, for instance, fourteen days. On other ditches, irrigation time depends on acreage, with smaller holders receiving less time. Maintenance duties are apportioned similarly, and with similar variation

Parciantes often informally share water amongst themselves via negotiations with the mayordomo (ditch boss) and their neighbors. This sharing, known as the reparto or repartimiento (Rodríguez 2006; Rivera 1998) keeps water not only in the same basin, but the same ditch. The NM Office of the State Engineer (OSE) has the power to decide whether an out-of-basin water transfer is acceptable, but they are possible (Nunn et al 1991; Johnson et al 1981).

Under the repartimiento, a farmer with senior water rights might allow a junior user to use a part of those rights for a specified period of time, without formally giving up the rights. When this takes place between different acequias, or between a group of acequias and another entity, another term used is "shortage sharing." The City of Las Vegas NM entered into a shortage sharing agreement with the acequias of the Gallinas River in 2006. Current drought conditions have resulted in negotiations over the sharing becoming extremely tense (J. Varela, New Mexico Acequia Association, personal communication with author).

Additionally, acequia associations might negotiate planting different types of crops depending on the snowpack. This commons approach to resource management was also applied to grazing cattle until quite recently in Hispano villages throughout northern New Mexico, and is not limited to agricultural decisions. Nor is it limited to New Mexico. Ingram \& Brown (1998) make the point that such practices are part of a "water comity" which has existed in every desert society, and of course not just in the desert (Boelens \& Davila, 1998; Berkes \& Folke, 1998; Maas \& Anderson, 1978), defined as "the observation of mutual courtesies." It is composed of three aspects: dependability of the resource, participation by pertinent communities, and opportunity for use in the future. Ingram \& Brown (1998) make the point that approaching water from a community valued perspec- 
tive does in no way diminish its economic importance, and therefore does not preclude even the most conventional economic analyses. Rather it enriches the analytical context.

The repartimiento allows reallocation of water within a community without users selling or trading their rights. Some advantages of this system over formal transfers are that it is a flexible system with relatively few transaction costs and that it keeps rights and therefore flows within the basin. The repartimiento is part of a greater constellation of what Rivera (1998) describes as "Acequia Culture" Rivera argues that acequia culture includes the continuity of Hispano traditions such as weaving and the carving of wooden saints or angels known as santos.

The teaching of these traditions is embedded in the communal focus of the acequia towns. The traditional notion of water rights in these towns is shared and participatory, deriving from Spanish and Islamic water law, rather than from the contemporary US (Anglo) ideas of private ownership of rights (Hutchins, 1928; Keleher, 1929). If the communities stop irrigating, Rivera argues, they stop working together. If they stop working together, they communicate less. This diminution of communication is the thin end of a wedge of cultural disintegration that could lead to the disappearance of traditional ways of teaching arts and crafts. While tenacious individuals will always hang on to and even perhaps revive these crafts in the absence of a functioning community, they will be far less common than they are now.

William Gonzales, a commissioner and irrigator in San Miguel County, argues that this lack of communication can permanently damage community-level governance. As people no longer work together or see each other on a regular basis, old interfamily disputes are more likely to persist, lands to be fenced off, and the community sets against itself, rather than working together to ensure provision of, for instance, water rights. Gonzales' attitudes are borne out in the small farming community of San Augustine, south of Las Vegas, NM. In San Augustine, irrigators are beginning to work together at the limpia (yearly ditch cleaning) for the first time in decades, and are working together to sue the City of Las Vegas in order to guarantee the delivery of their water rights, which are senior to the City's by approximately 30 years. Part of the reason the community lost access to its water was because people drifted away from agriculture, and substituted laborers during the limpia, or ignored it altogether.

This exodus was due to a number of variables. The principal reason was World War II, during which a large number of young New Mexican men were drafted and in many instances left their home counties and country for the first time in their lives. Other significant influences on the outmigration include a massive drought in the late 1950s, younger residents' joining the military during the Vietnam War, and a general move toward the City of Las Vegas (COLV) by many rural residents. Gonzales' point is that when farming disappears, a whole section of sub-municipal government disappears, and larger municipalities gain control of agricultural water, further diminishing the character of the counties. 


\section{San Miguel County and E1 Río de las Gallinas}

The Gallinas rises above El Porvenir Canyon northwest of COLV in the southeastern Sangre de Cristo Mountains near Elk Mountain at an altitude of about 11,660 feet (Evans \& Lindline, 2004; NMED, 2005; OSE, 1991), flowing roughly southeast before running through the City of Las Vegas, NM. Figure 1 shows the location of San Miguel County and the Gallinas River.

According to Saavedra (1987), there are 11 acequias that irrigate on the Gallinas; according to the Rio de las Gallinas Acequia Association (RGAA) at the time I conducted interviews (Pers. Comm with Joseph Padilla, then president of RGAA), there were 21 (12 community, nine private) active ditches. Speaking with Richard Cozens, the current president, that number has decreased to about " 13 operating community acequias and three to four private ditches." There are also two unadjudicated springs whose water is used for irrigation, two ditches whose existence is in doubt, one that is somewhere between being community and private, and several that no longer operate but are still discussed. The ditches and some infrastructure (e.g. headgates) still exist but no one uses them, as no one lives in the communities any more. However, they are so recently abandoned that they persist as part of the greater acequia community.

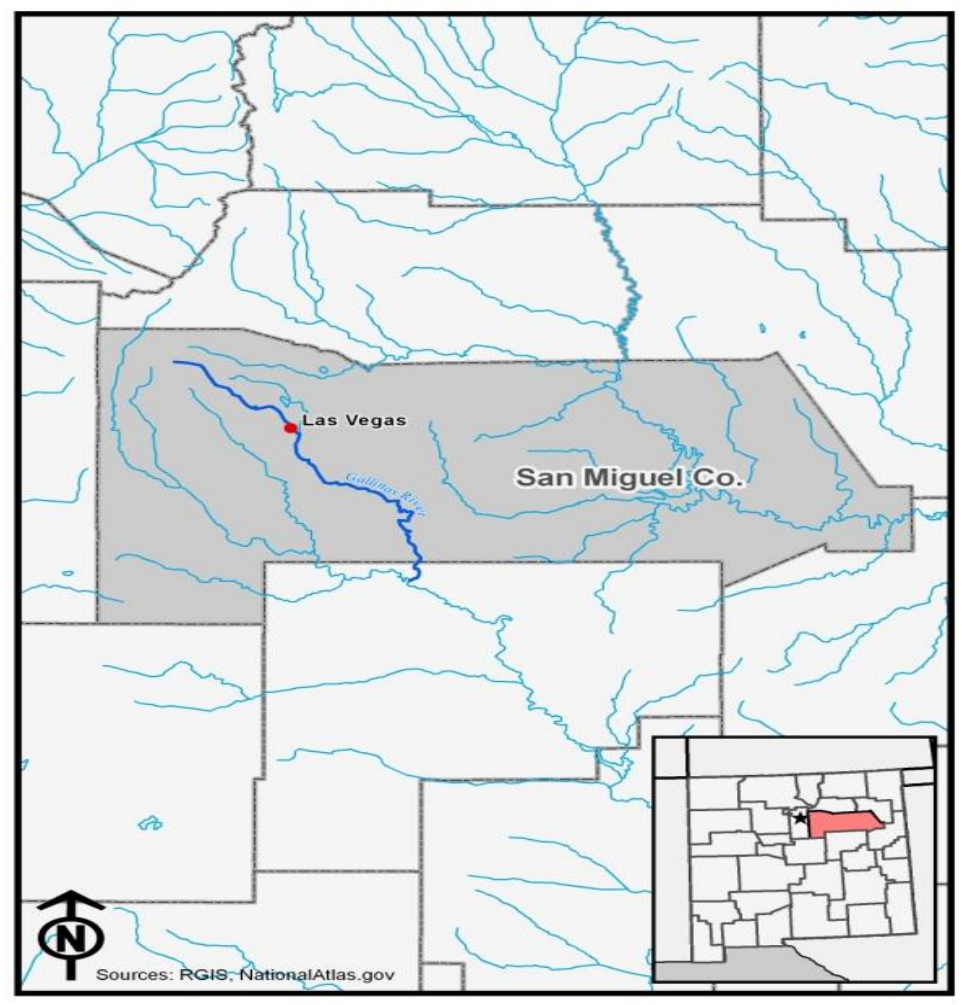

Fig. 1. Location of San Miguel County in the State of New Mexico 
There are three principal reaches on the Gallinas: upstream of the municipal diversion dam in Montezuma (upstream ditches), within city limits (middle ditches), and downstream of COLV's effluent return (downstream ditches). Above the municipal diversion are the villages of El Porvenir to Montezuma, and this reach includes the Placita Arriba, Upper Maestas, Maestas, and Luis Martinez ditches. The Middle Reach includes the Los Vigiles ditch above COLV, the Roundhouse ditch, los Romeros ditch, and the Acequia Madre de Las Vegas. South of COLV the river flows through the abandoned village Los Fuertes, San Augustine, and then on through the abandoned villages of Bereda Blanca, La Liendre and Chaperito before sometimes flowing in to the Pecos River near Dilia, NM, in Guadalupe County.

\subsection{Community Characteristics}

San Miguel County is located in the northeast of the state, east of the capital Santa Fe. It has an area of 4,717 square miles and a population of 29,301 out of New Mexico's total population of $2,082,224^{38}$. The county is roughly $76 \%$ Hispanic, roughly $20 \%$ Anglo, with about 3\% Native and 2\% Black residents. Median household income is $\$ 32,213$, considerably below the state median of $\$ 43,820$. Approximately one fourth $(24.8 \%)$ of the county's population lives below the poverty line, compared with $18.4 \%$ of the state's population.

The Gallinas basin was settled relatively late for northern New Mexico (Arellano et al., 1998). The first settlers moved in after the establishment of San Miguel del Bado in 1794, and the grant of Las Vegas Grandes was founded in 1823 (NMED, 2005). Diversion dates on the Gallinas can seem recent compared to dates in other basins (Rodriguez, 2006; Hutchins, 1928). This late settlement is due to the fact that the original Spanish explorers came up the Rio Grande (Rivera, 2006), only crossing the Pecos Valley later and also in part, due to the persistence of the Comanche Nation (Arellano et al., 1998). Comanche continued to raid Hispano settlements into the early $20^{\text {th }}$ Century; parciantes recounted stories of their parents or grandparents being attacked or in one case killed by Comanche in the late $19^{\text {th }}$ or early $20^{\text {th }}$ centuries (Pers. Comm with respondents during interviews conducted by author in 2006-8).

\section{Values of Agricultural Ecosystem Services and Culture}

Ecosystem services are generally thought to be best provided by relatively pristine wetlands and forests (DeGroot et al., 2002; DeGroot et al., 2006). Agricultural land provides a variety of ecosystem services, such as open space (Kline \& Wichelns, 1994, 1996a, 1996b; Adelaja et al., 2006; Adelaja \& Lake, 2007; Plantinga \& Miller., 2001), wildlife habitat (Nickerson \& Lynch 2001), and groundwater recharge (Smith 2006; Fernald et al., 2007; Fernald \& Guldan, 2006). This constellation of amenities is also addressed in the agriculture multifunctionality literature (Drake, 1992; Randall, 2002: Rønningen et al., 2004; Groenfeldt, 2005). Table 1 displays results from valuation work on agriculture and some other cultural ecosystem services.

Swinton et al. (2007) compare results from a choice experiment (CE) and a method called "Analytical Hierarchy Process" to ascertain how the Scottish public views various ways to improve agricultural sustainability. Lockwood et al. (1996), comparing competing uses involving two nonmarket (and cultural) resources, measure the value of grazing in the Australian Alps. Much like New Mexico, grazing in the alpine areas is regarded as inherent to the local culture, even though many Australians recognize the environmental damage these practices can create. 
Australians recognize the environmental damage these practices can create. Johnston et al. (2001) compare results from a contingent choice survey and hedonic pricing research to assess non-market values for different types of agricultural land in Suffolk County NY. Halstead (1984) found that WTP to preserve agricultural land near the respondents' homes in three towns in Massachusetts increased as intensity of suggested development increased and found a value of up to $\$ 176.06$ per household to avoid heavy development.

Table 1. Valuation research on agricultural land and indigenous culture

\begin{tabular}{|c|c|c|c|c|c|c|}
\hline Authors & Year & Good valued & Location & WTP* & Currency & 2008 US\$ \\
\hline Han et al. & 2008 & $\begin{array}{l}\text { Pre-Buddhist re- } \\
\text { mains }\end{array}$ & Korea & $\# 254.43$ & $\begin{array}{l}\text { Korean } \\
\text { Won }(2008)\end{array}$ & $\$ 2.12 / \mathrm{hh}:$ \\
\hline \multirow[t]{2}{*}{$\begin{array}{l}\text { Swinton et } \\
\text { al. }\end{array}$} & \multirow[t]{2}{*}{2007} & $\begin{array}{l}\text { Options for agri- } \\
\text { environmental poli- } \\
\text { cy: Environmental } \\
\text { improvements }\end{array}$ & \multirow[t]{2}{*}{ Scotland } & $\begin{array}{l}£ 50.94- \\
£ 55.27\end{array}$ & $\mathrm{~GB} £(2006)$ & $\begin{array}{l}\$ 106.48- \\
\$ 115.50\end{array}$ \\
\hline & & Rural Development & & $\begin{array}{l}£ 50.07- \\
£ 74.01\end{array}$ & & $\begin{array}{l}\$ 106.00- \\
\$ 154.72\end{array}$ \\
\hline Noonan & 2003 & $\begin{array}{l}\text { Meta-analysis on } \\
\text { cultural goods }\end{array}$ & Worldwide & $\$ 42.78$ & US\$ (2002) & $\$ 50.13$ \\
\hline Boxall et al. & 2003 & $\begin{array}{l}\text { Canoeists' WTP to } \\
\text { see pristine aborigi- } \\
\text { nal rock art }\end{array}$ & Canada & $\$ 77 \dagger$ & $\begin{array}{l}\text { Not stated, } \\
\text { assumed to } \\
\text { be } 2003 \\
\text { CA } \$\end{array}$ & \\
\hline $\begin{array}{l}\text { Johnston et } \\
\text { al. }\end{array}$ & 2001 & $\begin{array}{l}\text { Protection of dif- } \\
\text { ferent types of agri- } \\
\text { cultural land }\end{array}$ & USA & $\begin{array}{l}\$ 1,199 / \text { acre } \\
/ \text { year }\end{array}$ & US\$ (2001) & $\$ 1460.48$ \\
\hline \multirow[t]{2}{*}{$\begin{array}{l}\text { Lockwood et } \\
\text { al. }\end{array}$} & \multirow[t]{2}{*}{1996} & $\begin{array}{l}\text { WTP to stop cattle } \\
\text { grazing }\end{array}$ & Australia & $\$ 30$ & & $\$ 39.31$ \\
\hline & & $\begin{array}{l}\text { WTP to continue } \\
\text { grazing but mitigate } \\
\text { ecological effects }\end{array}$ & & $\$ 73$ & AU\$ 1996 & $\$ 95.67$ \\
\hline Halstead & 1984 & $\begin{array}{l}\text { WTP to avoid de- } \\
\text { velopment on sur- } \\
\text { rounding farmland }\end{array}$ & USA & $\$ 176.06$ & US\$ (1984) & $\$ 365.34$ \\
\hline $\begin{array}{l}\text { Notes: *WTP } \\
\text { Currency con } \\
\text { http://www.r } \\
\text { Conversions }\end{array}$ & istec & $\begin{array}{l}\text { per household (/hh) } \\
\text { ed http://www.xe.co } \\
\text { fed.org/Research/da } \\
\text { ry at time of research }\end{array}$ & cept $t$, whi & $\begin{array}{l}\text { per respon } \\
\text { i and } \\
\text { accessed } M\end{array}$ & 30,2008 & \\
\hline
\end{tabular}

The valuation of culture is somewhat more complicated. Defining culture is not as straightforward as defining ecosystem services, complicated as that can be. The Convention for the Safeguarding of Intangible Cultural Heritage (UNESCO, 2003) defines "intangible cultural heritage" as the "practices, representations, expressions, knowledge, skills -as well as the instruments, objects, artefacts and cultural spaces associated therewith- that communities, groups and, in some cases, individuals recognize as part of their cultural heritage." The Convention states that this heritage can manifest in "oral traditions and expressions, performing arts, social practices, rituals, and festive events, knowledge and practices concerning nature and the universe, and traditional craftsmanship." 
While there is a cultural economics literature, it tends to focus on cultural goods such as symphonies and museums (Noonan, 2003; Rushton, 1999). There is not an extensive literature on how to value cultural-behavior attributes. Throsby (2003) argues that this is not necessarily a problem, as "a distinguishing feature of cultural goods is that acquiring a taste for them takes time, i.e. they are classed as experiential or addictive goods, where demand is cumulative, and hence dynamically unstable (p. 277)." One result of this is that nonmarket valuation methods might not fully capture WTP from insufficiently informed participants.

Another issue raised by Throsby (2003) is that cultural goods could be seen by individuals as playing an important role in the utility function of a larger group, and therefore WTP values might not be well-captured via individual utilities. Rushton (1999) argues that conventional economic valuation techniques, predicated on Methodological Individualism, start from given behavior without research into what formed that behavior, and do not necessarily capture the societal value of cultural goods for much the same reason.

Noonan (2003) provides a meta-analysis of the valuation work on cultural goods, reviewing 65 CVM studies on cultural resources. Boxall et al. (2003), using a combined revealedand stated-preference approach, examine canoeists' values for pristine or defaced aboriginal rock paintings along canoe routes in Canada's Precambrian shield area. Han et al. (2008) conducted a choice experiment to ascertain the value of natural resource damages arising from the construction of a large dam on the Tong River in Korea. They described four attributes: Forest, Fauna, Flora, and Remains, defined as "protection levels of historical remains (p. 258)." This last attribute showed the highest mean W'TP, at 254.43 (US\$2.12) Korean Won per household. This suggests that this sample valued cultural services most highly for this project. Aggregating these values across the households in the affected population, total WTP for the entire population was approximately 209.9 billion Korean Won (US \$ 174.9 million) per year. The authors recalculated the project's proposed benefit cost ratio (BCR), which changed from 1.02 to 0.85 . At any point below unitary (where $\mathrm{BCR}=1$ ), a project cannot be recommended on a cost-benefit basis.

\section{Contingent Valuation}

In a CVM survey, respondents are presented with a hypothetical scenario, a specific change (or set of changes) in an environmental program or policy, a payment vehicle, and then an economic choice. Specifically, respondents are asked to make statements about their willingness to pay ("WTP") or to willingness to accept ("WTA") compensation for the proposed changes in environmental quality or access. Common elicitation formats for asking valuation questions include both open-ended ("OE") and closed-ended formats (Bishop et al., 1995). The latter includes the dichotomous choice ("DC") format where respondents must either accept or reject a given payment amount for the proposed change in environmental quality or access. DC formats include the hypothetical referendum format, as advocated by Arrow et al. (1993). Payment card ("PC") is another closed-ended format, wherein respondents are given a set of value options to choose from.

There is support for both formats. Arrow et al. (1993) recommend DC, while Boyle (2003) states that OE might have an advantage over other formats as it avoids bid anchoring. DC more closely approximates a market, as consumers are given prices, rather than asked to determine them, and $\mathrm{OE}$ questions might be more challenging for some respondents, which could result in non-response or underestimation of WTP (Loomis \& White, 1996). Cameron et al. (2002) find that OE formats tend to produce more conservative WTP estimates than DC. In this research, I use OE, and apply the Tobit model (Boyle, 2003), which doesn't al- 
low negative values and accommodates a probability spike at zero $(\$ 0)$. I also use a referendum question and analyze those values using a Logit model (see below).

\subsection{Survey Design}

I conducted interviews about the valuation question with stakeholders from the irrigating community; irrigators from the Río de las Gallinas Acequia Association in Las Vegas NM, and the villages of Embudo and Cañon, NM, and staff from the NM Office of the State Engineer and New Mexico Legal Aid. After several iterations, the good provided was a training program for acequia farmers that included material on dryland farming techniques, water law, and conservation methods. This program would seek to:

1. Strengthen traditional culture and practices

2. Strengthen community ties

3. Improve communication between acequia-irrigated farms and state water agencies

4. Help conserve water on acequia-irrigated farms

5. Help acequia-irrigated farms adapt to climate change

After initial development of the instrument, contents and presentation were refined using focus group-type interviews with both irrigating and non-irrigating residents in Ribera and Las Vegas, NM. The survey was given to 10 people in interview format to test for comprehension and to ensure that as far as possible the survey instrument was unbiased ${ }^{1}$. Respondents were asked to describe any difficulties or problems they had with the survey. Attitudinal and demographic questions were included to facilitate interpretation of WTP results and check for sample representativeness. The 20-page survey is attached as Appendix 1.

The survey began with questions regarding use of water in San Miguel County, knowledge of acequia irrigation issues, knowledge of and opinions about cultural issues relating to acequias. The actual valuation question came in four parts: a description of the program, a hypothetical referendum question, a description of the payment mechanism and the valuation question itself.

The first part was a description of the training program. Respondents were then asked to rank how important, if at all, they felt such a program would be, on a score of 1 (Not Important) to 5 (Extremely Important). The survey described a hypothetical referendum, which asked whether participants would vote "yes" or "no" to a designation of the program. This was followed by a question about payment. The payment vehicle was a one-time payment directly into a fund administered by a "combination of Acequia Associations, and other local groups." If respondents answered "yes" to the latter question, they were asked to indicate the maximum their household would be willing to contribute. The survey concluded with an opportunity to discuss reasons for their support or lack of support for the designation attitudinal questions, and standard demographic questions.

The survey was mailed to a sample of 1500 residents of San Miguel County, randomly selected from a voter registration list. The survey was designed to be sent by mail due to a relatively low level of internet connectivity in the county at the time. The adjusted response rate (adjusted for 12 undeliverable surveys) was $9.5 \%$, providing a potential usable sample of $\mathrm{n}=143$.

\footnotetext{
${ }^{1}$ These participants were recruited via radio announcements on Frank Splendoria's show "The Back Porch" on KNMX AM and postings in the community announcements sections of several newspapers: the Las Vegas Optic and the Santa Fe New Mexican, which were described to me as the most commonly read papers in the area.
} 


\section{Empirical Results}

The sample in this research is not representative of the county. Compared to the county as a whole, this sample is better-educated and with a higher income than the county means ${ }^{2}$. Anglos are a greater proportion of the sample than of the county, though the sample and the county are both about 50\% female. Rural residents make up approximately $30 \%$ of this sample, but $50 \%$ of the population.

Table 2. Selected descriptive statistics for San Miguel County

\begin{tabular}{|c|c|c|}
\hline & $\begin{array}{l}\text { US } \\
2000\end{array}$ & $\begin{array}{l}\text { This research (standard errors in paren- } \\
\text { theses) }\end{array}$ \\
\hline Population & 29,325 & $\mathrm{~N}=143$ \\
\hline $\begin{array}{l}\text { Mean In- } \\
\text { come* }\end{array}$ & $\$ 13,268$ & $\$ 48,021(35,721.7)$ \\
\hline$\%$ Hispanic & 77 & $51(0.50)$ \\
\hline$\%$ Anglo & 20 & $35(0.48)$ \\
\hline$\%$ Female & 51 & $46(0.50)$ \\
\hline $\begin{array}{l}\% \text { of popula- } \\
\text { tion living in } \\
\text { an urban area }\end{array}$ & 50 & $30(0.46)$ \\
\hline $\begin{array}{l}\text { Notes: } \\
* \text { Mean income } \\
\text { come category } \\
\text { and } \$ 200,000 \text {. } \\
\text { est value was s } \\
\text { calculated for } t \\
* * \% \text { of popul } \\
\text { self-identifying } \\
\text { vided by the pc }\end{array}$ & $\begin{array}{l}\text { in sample calculate } \\
\text { except the two hig } \\
\text { There were so few } 1 \\
\text { lected so as not to } \\
\text { le entire sample. } \\
\text { tion living in urbat } \\
\text { as such. In Census } \\
\text { pulation of San Mig }\end{array}$ & $\begin{array}{l}\text { d as follows: midpoint was calculated per in- } \\
\text { hest. The two highest were left as } \$ 150,000 \\
\text { respondents in those categories that the low- } \\
\text { skew the categorical means. A mean was then } \\
\text { area defined in this research as respondent } \\
\text { data, I used the population of Las Vegas di- } \\
\text { guel County. }\end{array}$ \\
\hline
\end{tabular}

\subsection{Referendum Results}

Based on prior experience and the literature, it seemed that several variables would influence the decisions both to vote for the program and the WTP decision. Political affiliation could have an effect on the decision to vote for the program, as it could be hypothesized that more conservative respondents would not favor programs using state funds to support what is essentially a private undertaking. There was very little variation in the category of political affiliation, so these variables were not used in the regression. I had also thought that whether a respondent farmed or belonged to an acequia would be meaningful. So few acequia irrigators $(n=22)$ or agriculturists $(n=23)$ responded that I was unable to include those categories in my regressions.

There were also attitudinal questions that would have been important, such as how the respondent felt about irrigated agriculture in San Miguel County, such as how they felt about selling water rights. While there was sufficient variation in many of these responses, and an

\footnotetext{
2 Pearson's Chi-Squared test finds a highly significant difference in education levels between this research and that reported in the 2000 US Census $\left(\chi^{2}=24.07\right.$, p-value $\left.=0.0001\right)$.
} 
adequate number of responses, many of these variables proved to have no significance in the models, and were dropped. Two variables that were consistently significant were the questions on paying higher water rates (HIRATE) in the future and on selling water rights (SELRIGHT). It is difficult to make predictions about the effect of income ${ }^{3}$ on the decision to vote on the referendum. As that decision is costless, income should not make a difference. In terms of ethnicity, it is assumed that as the acequias are seen as a Hispanic heritage, whether the respondent is Hispanic might have a positive effect on the decision to vote YES. Therefore the models included an ethnicity dummy ${ }^{4}($ Hispanic $=1$, other $=0)$, and a location variable (rural $=1$, urban $=0$ ). With a few exceptions, the hypotheses in both this section and the section on W'TP are presented in two ways. The first presentation will be a one-tailed t-test examining whether the mean from one group is different from another. The same idea will then be restated in a two-tailed way that allows for examining the sign on the coefficient of the variable in question. As such there are different cutoffs for significance in each case.

This motivates the first hypothesis about voting behavior: Hispanic respondents are more likely to vote YES for the program than Anglo respondents. In terms of model testing, this can be stated as follows: that the coefficient on the Hispanic dummy is expected to be greater than zero, or:

\section{H1VOTE: $\beta$ Hispanic $>0$}

If a respondent is urban5, it seems plausible that they might see the acequias as a contender for their water. This would make urban residents less likely to support acequia culture programs financially. The few ditches in the City of Las Vegas are unlikely to make a difference. The opposite would likely hold true for rural residents. With acequias being in general a rural phenomenon, there might be more support for them in rural communities.

The HIRATE variable designates response to the question "We will probably need to pay higher water rates in the future." Possible responses were a 0-5 Likert-type scale, with higher values signifying stronger agreement with the statement. The HIRATE variable was modified to be a dummy variable. Due to a lack of variation in the variable, the upper two categories of response, 4 and 5, were combined to form the new dummy HIRATEHI, the rest of the categories $(1,2$, and 3$)$ were combined as HIRATELO. HIRATEHI produced betterperforming models and marginal effects. HIRATELO was not used in the regressions.

This motivates a second hypothesis, that rural respondents are more likely to vote for the program than are urban respondents. In terms of model testing, this hypothesis can be rewritten as:

\section{H2VOTE: ßrural>0}

Whether the respondent thinks that paying higher water rates in the future is largely an economic question, and its relevance to the voting decision is difficult to predict. However, the question on selling water rights is meant to proxy attitudes about keeping traditional practices in use, so the more a respondent agrees with the statement that selling water rights separately from one's land is not related to community opinion, the less the respondent is likely concerned with maintaining traditional community values of water management, and therefore the less they would be concerned with providing the program. This, then, motivates the third and final hypothesis on voting behavior, that those who agree with the SELRIGHT

\footnotetext{
3 In the regressions, income was broken into five categories, $<\$ 24,999 / \mathrm{yr}, \$ 25,000-\$ 39,999 / \mathrm{yr}, \$ 40,000$ $\$ 59,999 / \mathrm{yr}, \$ 60,000-\$ 99,999 / \mathrm{yr}$, and $\$ 100,000-\$ 200,000 / \mathrm{yr}$.

4 The self-identifying ethnicity question is taken from the US census; HISPANIC is whether respondents self-identify as Hispanic.

5 Self-identifying as living in an urban area, as opposed to a rural area-RURAL.
} 
question will be more likely to vote YES for the program than those who disagree. Following the above arguments, this can be rewritten as:

H3VOTE: $\beta$ sellright $>0$

Table 3 describes the expected effects of selected variables on the dependent variable VOTE.

Table 3. Predicted Effects of Independent Variables on the dependent variable VOTE.

\begin{tabular}{lll}
\hline Hypothesis & Variable & Expected sign \\
& & \\
\hline \multirow{3}{*}{$H_{\text {IVOTE }}$} & INC & $?$ \\
$H_{2 \text { VOTE }}$ & HISPANIC & + \\
& RURAL & + \\
$H_{\text {ЗVOTE }}$ & HIRATEHI & $?$ \\
\hline
\end{tabular}

Table 4: Responses to the Referendum Question and Descriptives for Explanatory Variables

\begin{tabular}{llllll}
\hline & $\begin{array}{l}\text { Overall Sample } \\
\text { (percentages in parentheses) }\end{array}$ & Ango & Hispanic & Urban & Rural \\
\hline N= & 129 & 47 & 70 & 36 & 88 \\
YES & $91(70.5 \%)$ & $34(72 \%)$ & $48(69 \%)$ & $21(58 \%)$ & $66(75 \%)$ \\
NO & 38 & 13 & 22 & 15 & 22 \\
HISPANIC & 85 & - & - & 57 & 28 \\
RURAL & 91 & & & & \\
SELLRT* & 134 & 34 & 41 & - & - \\
DISAGREE & 66 & 48 & 72 & 91 & 39 \\
NEUTRAL & 23 & 29 & 30 & 47 & 17 \\
AGREE & 45 & 7 & 14 & 19 & 4 \\
HIRATEHI & 103 & 12 & 28 & 25 & 18 \\
& & 40 & 52 & 70 & 30 \\
\hline
\end{tabular}

\footnotetext{
Notes:

*: "To what extent, if any, do you agree with the statement "People should be able to sell their water rights separately from their land, no matter what the community thinks." Five-point Likert-type question with $1=$ disagree strongly, $2=$ disagree somewhat, $3=$ neutral, $4=$ agree somewhat, $5=$ agree strongly. The category "disagree" captures a 1 or a 2 ; "neutral" is a 3 , "agree" is a 4 or a 5 .
} 
Table 4 shows responses to the vote question by subcategory. The program was supported by all major stakeholder groups, with "yes" receiving a majority vote among Anglos, Hispanics, urban, and rural residents. The program passed with a YES vote of $70.5 \%$ in the whole sample. This research could be said to present with $95 \%$ confidence that between 60 and $80 \%$ of San Miguel County residents support the designation of the acequia training program $^{69}$. This is a considerable degree of variation, and representative accuracy would be improved by increasing the sample size. Despite that, it appears that the measure would in general be supported by residents of San Miguel County.

The rural group voted YES at 75\%, and the urban group voted YES at 58\%. A two-sample $\mathrm{t}$-test found a significant difference between rural and urban residents at the $10 \%$ level $(\mathrm{t}=$ $1.8517, \mathrm{P}>|\mathrm{t}|=0.0665)$. Hispanic voters supported the program at $69 \%$, as compared to others at $72 \%$. A two-sample t-test found no significant difference in voting behavior by ethnicity (Hispanic=1, Anglo $=0)(\mathrm{t}=-0.4331, \mathrm{P}>|\mathrm{t}|=0.6658)$.

\subsection{Vote Data Modeling}

I used a Logit model to model the responses to the referendum question. The Logit model is a binary-choice dependent variable model, which assumes a logistic distribution of the error term. The Logit uses Maximum Likelihood Estimation to obtain $\sigma^{2}$, and the vector of coefficients $\beta$. The variable $y^{*}$ is used in the index function, and in this model takes the values of either 0 or 1 . The zero value indicates that a choice was not made, and a one (1) indicates that it was. However, we do not actually observe the utility function, simply the outcome of whether utility derived from some action is sufficient to undertake it (1) or not (0).

The likelihood function is given by:

$L=\prod_{Y_{i}=1} P_{t}^{Y_{i}} \prod_{y_{i}=0}\left(1-P_{t}\right)$

Taking $\log \mathrm{s}^{70}$, the Log-likelihood function for the Logit model is:

$\ln L=\sum_{t=1}^{n} Y_{t} \ln \left(P_{t}\right)+\sum_{t=1}^{n}\left(1-Y_{t}\right) \ln \left(1-P_{t}\right)$

I used the model to determine the probability that a respondent would vote "yes" to the referendum question (Q10) for a given set of demographic characteristics and a given set of responses to the survey questions. The wording of the question is:

Suppose the designation of the Acequia Farmer Training Program was subject of a nonbinding, countywide advisory referendum, where the results were provided to county, state, and local policy-makers. Would you vote Yes (for the designation) or No (against the designation)?

Based on the hypotheses in Table 3, I tested three specifications of Logit models. Table 5 shows results including marginal effects from the Logit estimations.

The Logit models generally showed reasonable performance based on McFadden's $\mathrm{R}^{2}$ $(\sim 0.20)$, and the variables behaved generally as predicted. The coefficients for the Logit 
model are not usable as probabilities, and so marginal effects were also calculated, in order to analyze $\mathrm{dy} / \mathrm{dx}$. For the significant variables in specification 1, marginal effects can be interpreted as follows. For income, a change of one income category would increase the probability of voting "YES" by 4\%; as a respondent's agreement with the statement about paying higher water rates increased by one category, the probability of their voting "YES" increases by $8-34 \%$. The marginal effects of a respondent's living in a rural area are slightly significant only in one instance, and as such it is hard to determine marginal effects in that case, but the effects were $10-18 \%$, depending on model specification.

Income is consistently positively and significantly correlated with that decision. The respondent's being Hispanic was negative but not significant, so we can reject the second hypothesis. The third hypothesis, that the selright variable would be positively correlated with VOTE, cannot be rejected.

\begin{tabular}{|c|c|c|c|c|c|c|}
\hline Variables & 1 & MFX & 2 & MFX & 3 & MFX \\
\hline INTERCEPT & $-2.60 * *(1.05)$ & & $-2.18^{* *}(0.84)$ & & $-2.73^{* *}(1.05)$ & \\
\hline INC & $0.23 * * *(0.07)$ & $0.04 * * *(0.01)$ & $0.23 * * *(0.07)$ & $0.04 * * *(0.01)$ & $0.21 * * *(0.69)$ & $0.04 * * *(0.01)$ \\
\hline HISPANIC & $-0.34(0.54)$ & $-0.05(0.08)$ & $-0.29(0.51)$ & $-0.05(0.08)$ & - & - \\
\hline RURAL & $1.02 *(0.54)$ & $0.18^{*}(0.10)$ & $0.93 *(0.53)$ & $0.16(0.10)$ & $0.99 *(0.51)$ & $0.10(0.10)$ \\
\hline HIRATEHI & $1.73 * * *(0.55)$ & $0.34 * * *(0.12)$ & $1.62 * * *(0.54)$ & $0.32 * * *(0.12)$ & $0.49 * *(0.21)$ & $0.08 * * 8(0.11)$ \\
\hline SELLRT & $0.11 *(1.05)$ & $0.02(0.03)$ & - & - & - & - \\
\hline Pseudo $\mathrm{R}^{2}$ & 0.2061 & & 0.2008 & & 0.1982 & \\
\hline $\mathrm{N}$ & 111 & & 112 & & 112 & \\
\hline$\chi^{2}$ & $25.84^{* * *}$ & & $25.29 * * *$ & & $24.96^{* * *}$ & \\
\hline
\end{tabular}

Notes: Standard Errors in parentheses.

*Significant at the $10 \%$ level; ** Significant at the 5\% level; ***Significant at the $1 \%$ level $\dagger d y / d x$ is for a discrete change of dummy variable from 0 to 1

\subsection{WTP Results}

Previous research and experience during other phases of data collection motivate a set of behavioral hypotheses related to WTP. Table 6 describes the expected effects of variables on the dependent variable WTP.

Table 6. Predicted Effects of Independent V ariables on the dependent variable WTP.

\begin{tabular}{lll}
\hline Hypothesis & Variable & Expected sign \\
\hline$H_{1 W T P}$ & INC & + \\
$H_{2 W T P}$ & HISPANIC & + \\
$H_{3 W T P}$ & RURAL & + \\
& HIRATEHI & $?$ \\
$H_{4 W T P}$ & SELRIGHT & - \\
\hline
\end{tabular}


Table 7 provides the distribution of sample responses to the willingness to pay question. The sample mean was $\$ 25.00 / \mathrm{hh}$, with a standard deviation of $\$ 54.48$. While the minimum was $\$ 0.00$ and the maximum was $\$ 500.00$, that maximum value was an outlier. There were 87 zero-valued responses, $61.7 \%$ of the total response. Of those who responded, $59.7 \%$ of Hispanics and $57 \%$ of Anglos chose a zero-valued response. Forty-four out of 91 YES voters (48.4\%) chose a WTP response of zero. The mean Anglo WTP was \$29.22, and mean Hispanic WTP was $\$ 17.74$. A two-sample t-test revealed a statistically significant difference between Anglo and Hispanic WTP at the 5\% level $(\mathrm{t}=-1.9593, \mathrm{P}>|\mathrm{t}|=0.0524)$. Rural mean WTP was $\$ 32.58$, and urban $\$ 12.20$. T-tests revealed a significant difference between urban and rural WTP $(t=1.9728, \mathrm{P}>|\mathrm{t}|=0.0507)$ at the $5 \%$ level.

Table 7. Descriptive Statistics on Willingness to Pay.

\begin{tabular}{llllll}
\hline Description & $\mathrm{N}$ & Mean & SD & Min & Max \\
\hline Sample & & & & & \\
Hispanics & 143 & $\$ 25.35$ & 54.48 & 0 & 500 \\
Anglos & 73 & $\$ 17.74$ & 28.52 & 0 & 100 \\
Male & 58 & $\$ 29.22$ & 45.26 & 0 & 200 \\
Female & 65 & $\$ 31.31$ & 71.54 & 0 & 500 \\
Rural & 65 & $\$ 21.85$ & 33.91 & 0 & 100 \\
Urban & 91 & $\$ 32.58$ & 63.53 & 0 & 500 \\
\hline
\end{tabular}

Table 8. Variable coefficients and marginal effects ${ }^{\dagger}$ (MFX) from Tobit model estimations

\begin{tabular}{|c|c|c|c|c|c|c|}
\hline Variables & 1 & $\overline{\text { MFX }}$ & 2 & $\overline{\text { MFX }}$ & 3 & $\overline{\text { MFX }}$ \\
\hline INTERCEPT & $-2.60^{* * *}(1.05)$ & & $-2.18^{* *}(0.84)$ & & $-273^{* *}(1.05)$ & \\
\hline $\mathrm{NC}$ & $0.23^{* 1 * *}(0.07)$ & $0.04^{* k *}(0.01)$ & $0.23^{* 1 * *}(0.07)$ & $0.04^{* * * *}(0.01)$ & $0.21^{* 1 * k}(0.69)$ & $0.04^{* * k}(0.01)$ \\
\hline HISPANIC & $-0.34(0.54)$ & $-0.05(0.08)$ & $-0.29(0.51)$ & $-0.05(0.08)$ & - & - \\
\hline RURAL & $1.02^{*}(0.54)$ & $0.18^{*}(0.10)$ & $0.93^{*}(0.53)$ & $0.16(0.10)$ & $0.99 *(0.51)$ & $0.10(0.10)$ \\
\hline HIRATEHI & $1.73^{* 1 * k}(0.55)$ & $0.34 * * *(0.12)$ & $1.62^{* * *}(0.54)$ & $0.32^{* 1 * *}(0.12)$ & $0.49^{* *}(0.21)$ & $0.08^{* * 8} 8(0.11)$ \\
\hline SEIJRT & $0.11^{*}(1.05)$ & $0.02(0.03)$ & - & - & - & - \\
\hline Pseudo $\mathrm{R}^{2}$ & 0.2061 & & 0.2008 & & 0.1982 & \\
\hline $\mathrm{N}$ & 111 & & 112 & & 112 & \\
\hline$\chi^{2}$ & $25.84^{* \text { twk }}$ & & $25.29^{\text {*tak }}$ & & $24.96^{* 2 k x}$ & \\
\hline
\end{tabular}

Notes: Standard Errors in parentheses.

*Significant at the $10 \%$ level; ** Significant at the 5\% level; ***Significant at the $1 \%$ level

$\dagger d y / d x$ is for a discrete change of dummy variable from 0 to 1 


\subsection{WTP Data Modeling}

Given the design of the open-ended (OE) valuation question (Question 11), I estimate several single-equation willingness to pay (WTP) models:

$W T P_{i}=\beta x_{i}+e_{i}$

where $\mathrm{x}$ is a vector of characteristics for household $\mathrm{i}$, and $\beta$ is the vector of corresponding parameters to be estimated. A primary consideration in estimating WTP is that WTP responses from survey data often consist of numerous zeroes. In these data there were 87 zero responses out of a total of 141. Because so many observations of the WTP variable are zero-valued, classical linear regression methods are not appropriate ${ }^{66,71,70}$, and the Tobit (or Tobin's Probit) model is recommended to estimate the WTP function. The Tobit model is a censored regression model on a continuous dependent variable that assumes an error term with a standard normal distribution.

Maddala $^{70}$ and Greene ${ }^{71}$ state that censoring a distribution is required if the researcher only wants to record values of $\mathrm{y}^{*}$ with values greater than some constant $\mathrm{c}$, in this case, $\mathrm{c}=0$, so the Tobit model uses WTP values greater than zero, and the distribution must be censored at zero, resulting in what Greene calls the "censored normal" distribution. In WTP research, "protest votes" of $\$ 0.00$ are common ${ }^{72}$. To ensure that the distribution integrates to one, it should be scaled up by the probability that an observation in the uncensored population falls in the range of interest. This is essentially the transformation carried out by the Tobit model. In this case a new random variable y is presented such that:

$y=0$ ify $x \leq 0$,

$y=y *$ if $y * \mathbf{0}$

The Tobit makes the mean in the censored normal distribution correspond to a standard normal distribution, allowing a conventional regression on the new transformed distribution. The Tobit model is formulated in terms of an index function:

$W T P_{i}=\beta^{\prime} x_{i}+e_{i}$ where $e_{i} \sim N\left(0, \sigma^{2}\right) i=1, \ldots, N$ households

$W T P_{i}=0$ if $W T P_{i}^{*} \leq \mathbf{0}$

$W T P_{i}=W T P_{i}^{*}$ if $W T P_{i}^{*}>\mathbf{0}$

where $\beta^{s}$ is a vector of parameters on the independent variables xi, and ei is the error term. Here we can see how the Tobit in this instance simply replaces the dependent variable of interest WTP* for $\mathrm{y}^{*}$ of the general form, and only performs the regression for observed values above zero.The log-likelihood function is:

$$
\ln L=\sum_{W T P_{i}=0} \ln \left[1-\Phi\left(\frac{\beta^{\prime} x_{i}}{\sigma}\right)\right]-\sum_{W T P_{i}>0} \frac{1}{2}\left[\ln (2 \Pi)+\ln \sigma^{2}+\frac{\left(y_{i}-\beta^{\prime} x_{i}\right)^{2}}{\sigma^{2}}\right]
$$


Table 8 shows results including marginal effects and estimated WTP $(\overrightarrow{W T P})$ from the Tobit estimations.

The models in general predicted higher WTP (approximately \$30.00) than the sample means. Model performance was low, with a pseudo (McFadden) $R^{2}$ of less than 0.03 . In all models, INC was positively significantly correlated with WTP, as predicted. The ethnicity dummy tended to be negative, but not significant. RURAL was positive and significant in each model, as expected, and HIRATEHI proved to be positive and significant in each model.

Just as in the Logit model, coefficients from direct estimation of the Tobit model do not provide probabilities, so in order to calculate $d y / d x$, marginal effects must be calculated. Marginal effects for the significant variables can be interpreted as follows. An increase of one income category increases WTP by $7 \%$. Agreeing with the statement that "we will probably have to pay higher water rates in the future," as opposed to either being neutral or disagreeing with it, increases WTP by around $70 \%$. This effect is greater than income or any other variable. The RURAL variable was not significant in the marginal effects calculations.

$\mathrm{H} 1$ is not rejected, but coefficients and marginal effects were insignificant for $\mathrm{H} 3$ and for H4. The actual 95\% confidence interval is between $\$ 24$ and $\$ 26$. This is low compared to some other research: Swinton et al. (2007) found values in excess of $\$ 100.00$ for either "rural development," or "environmental programs" and Noonan (2003) found mean values equivalent to $\$ 50.13$ per household for various cultural goods.

\section{Discussion and Policy Implications}

One objective of this research was to ascertain residents' values for acequia irrigation and therefore culture in San Miguel County. There was both a high level of support $(70.5 \%)$ and a positive WTP $(\mu=\$ 25.00 / \mathrm{hh}$ ) for the program, though a majority of supporters had a WTP of $\$ 0.00$. Rural residents voted yes at a higher level $(75 \%$ vs. $58 \%)$ and showed a higher WTP ( $\$ 35.28$ vs. $\$ 12.20$ ) than the urban population. This is not surprising, though it contradicts Gardner's (1977) assertion that benefits of farmland preservation principally accrue to urban residents. Furuseth (1987) finds support for a "sociospatial" hypothesis, which suggests that support for protection programs is widely distributed in communities, and reflects a growing concern about rapid development in rural areas.

An unexpected result of this research is that Hispanics' WTP (\$17.74) for the program was much lower than that of Anglos (\$29.22). While it is possible that Hispanics do not value acequia culture as highly as Anglos, there are several other explanations. Income disparities can explain differences in WTP, but breaking income into categories8, a Pearson's $\chi^{2}$ test shows no significant difference between Hispanics and Anglos $\left(\chi^{2}=0.7126, \mathrm{p}\right.$-value $=$ 0.8702)9. So the answer does not appear to lie in income differences.

It is important to discuss some perceptions of the differences between Anglos and Hispanics in a New Mexican context. This is a large and entire area of study distinct from the sort of valuation exercise I conduct here, and I will discuss it only briefly as a background. The part of the USA that is now New Mexico was part of Spain and then Mexico until 1848 when it became a territory and then 1912 when it became a state (Keleher, 1929). The arrival of essentially an Anglo-Saxon jurisprudence and property rights regime (Simmons, 
1972; Hutchins, 1928) has never been fully integrated. Rather it has been grafted onto the "traditional" mix of Spanish and Indigenous property rights structures (Hall, 2012; Rivera, 2006).

During interviews I conducted between 2006-2008 in San Miguel County (Raheem, 2008), and based on ongoing conversations with local irrigators and scholars, some Hispanics still do not recognize the authority of, for instance, US Federal land management agencies, especially in uplands which were historically common grazing land (Pers. Comm with Estevan Arellano, October, 2005; Rivera, 1998; Rodriguez, 2006). This undercurrent of dissatisfaction and mutual distrust runs back as far as the United States has held administrative sway over the area, and runs both ways. Nieto-Phillips (2004) cites New York Times articles expressing suspicion about the loyalties of the "Mexican" residents of the territory during the Mexican-AmericanWar.

Along the Gallinas, "newcomers" are generally thought to be Anglo, but they are often Hispanic. Several irrigators describe new Hispanic families moving onto their ditches. Additionally, one mayordomo points out that new Anglo irrigators are often intensely concerned about being seen as outsiders, are receptive to traditions and local power structures, and make good neighbors.

One informant tells me of a conflict that ran for decades. "At one time he [the mayordomo] was having problems with the first Anglo on the ditch. He [the Anglo] would take all the water. Downstream users would not get any unless there was an abundance [of water]. He is still doing that. One irrigator was complaining that he didn't get any water. [The mayordomo] was self-employed. The irrigator asked him "why do you accept the responsibility of mayordomo if you have another job?" My husband had to go to the irrigator ['s gate] in the middle of the night, and would turn the water on at the headgate. The Anglo also had a key. [There was] no enforcement available to the mayordomo. Was it because the man was an Anglo, a wealthy Anglo, or a wealthy established Anglo?" This informant feels that the Hispanics took a back seat, but was not really sure why.

Bardhan (1993; p. 90) states "contact with outsiders and the option to exit reduce the effectiveness of social norms and the validity of the "common knowledge" assumption." The "option to exit" seems more salient in the acequia example. Conversations both during the interviews and the experiment suggest that until recently, few families sold their land or water rights. With the high property prices in certain counties, cash-poor irrigators and farmers rationally see opportunity in newcomers. So while "contact with outsiders" might provide the "option to exit," it is really the latter which drives change in these villages. On most of the Gallinas, the communities are so small that newcomers would be hard pressed to really change the norms structures in place. Throughout my interviews, and in ongoing communications with irrigators, there is still the persistent sense that Anglos and outsiders are causing most of the problems.

One explanation for the difference in WTP could lie in culture. Hispanic parciantes are not part of the dominant European culture in the US. Watkins (2005) refers to such a group as "intra-nationalist," describing them as "indigenous populations or other cultural, social, or religious enclaves within source nations (p. 79)." This intra-nationality could lead to one of the three problems brought up by Adamowicz et al. (2004, p. 53): "difficulties in aggregating indigenous and non-indigenous responses." Differences between traditional Hispano and Anglo property rights regimes might also be at the heart of this valuation disparity, 
with many Hispanics viewing water as a collectively owned good, rather than a privately owned one, which is the view taken by the prior appropriations doctrine.

Additionally, this research addresses cultural goods, which, while certainly not racially exclusive like aboriginal hunting rights, are here based in a non-Anglo society. During my interviews, conversations with ranchers and santeros (carvers of wooden saints) show a consistent feeling of betrayal and the robbery of Hispano heritage by Anglos over New Mexican history from territory to present. The notion that anyone would ask people to pay for a program to train them to do what they're already trying to do might seem insulting.

Another issue, discussed by Adamowicz et al. (1998) is how indigenous or traditional societies may have difficulty seeing certain goods as substitutable, either for each other or even for money. Many of the irrigators I interviewed spoke of acequia communities only recently being integrated into a cash economy. Many of these parciantes grew up in a barter economy, with "normal" cash transactions taking place with non-acequia goods, such as gasoline. Even automobiles could be obtained via barter (Peña, 2003). Godoy et al. (1995) found that, for the Summu Indians of Nicaragua, increases in cash incomes resulted in a "decline in the economic importance of forest goods in household incomes." While this is a broad comparison, something similar seems borne out in certain acequia communities, as integration into a cash economy makes the production of agricultural products less important to many individuals. With these products becoming less important, and sometimes not having a cash value to begin with, the related cultural aspects of acequia irrigation might not be seen as substitutable for money. Venn \& Quiggin (2007) also address this issue of non-substitutability, particularly with respect to sacred values in indigenous cultures, and recommend quantity-based rather than price-based substitutions in some indigenous resource-use policy analysis.

It is incorrect to state that the Hispanic community in San Miguel County values acequia culture less than any other group. Rather it seems that the proxy program or the payment mechanism somehow insufficiently represents or fits culture. If stakeholders and researchers are looking for a way to value acequia irrigation, culture, or even ecosystem services, we will have to conduct more extensive discussions in order to find a delta $\mathrm{q}$ that more closely represents the cultural asset I am here seeking to value. It is important to recognize the historic cultural disparities that prevail or persist in the region, and come to terms with them to make this sort of research effective.

One specific recommendation to any researcher involved in WTP research pertaining to acequias is to examine the subject community as thoroughly as possible. Much existing scholarship on acequias is by long-time residents of New Mexico. At least some future research will be conducted by outsiders. If economists using conventional welfare measures do not understand the underlying hierarchies, beliefs, and other issues of the groups surveyed, then their results will not be as informative as they could be. Additionally, some groups might simply oppose WTP as a useful measure. If WTP is to be used as a proxy for public welfare (as economic theory recommends) then we need to understand very clearly how different groups see WTP. If I had conducted this research with a Pueblo irrigating community, and found that their WTP was lower than their Anglo neighbors', how would we reconcile that? It might be important to examine what alternative measures can be used.

A second, broader objective is to motivate discussion about performing this kind of valuation at all, and to get agencies and individuals thinking about water use in more of an ex- 
plicit cost benefit framework. Bokum (1996) recommends some form of cost benefit analysis for water transfers that might affect the public welfare in NM, and the public welfare clause contains language that would seem to permit it, though it does not require it.

While agencies might deem it onerous to conduct this kind of work, obtaining explicit values for all the different types of uses to which water could be put in these basins could facilitate negotiations about alternatives. At the time of this writing, the Gallinas acequias, the City of Las Vegas, and other stakeholders are discussing a water sharing agreement. Obtaining some sort of clear values might be useful as part of this process. The effort of designing a comprehensive instrument would require participation from all groups, and that process alone would highlight perspectives that otherwise might not come out.

Acknowledgments. I would like to thank Kate Krause, Jenn Thacher, José Rivera, William Gonzales, Estevan Arellano, all the parciantes of El Río de las Gallinas, and two anonymous reviewers.

\section{References}

Adamowicz, W., Beckley, T., Hatton MacDonald, D., Just, L., Luckert,M., Murray, E., \& Phillips, W. (1998): "In search of forest resource values of indigenous peoples: Are nonmarket valuation techniques applicable?” Society and Natural Resources, 11(1), 51-66.

Adamowicz, W., Boxall, P., Haener, M., Zhang, Y., Dosman, D., \& Marois, J. (2004): “An assessment of the impacts of forest management on aboriginal hunters: Evidence from stated and revealed preference data". Forest Science, 50(2), 139-152.

Adelaja, S., \& Lake, M. B. (2007): Preserving Farmland and Achieving Agricultural Viability in the State of Michigan. A Viable Agriculture Report Prepared by the Michigan State University Land Policy Institute. Report \# 2007-3.

Adelaja, S., Lake, M. B., Colunga-Garcia, M., Hamm, M., Bingen, J., Gage, S., \& Heller, M. (2006): Acreage and Funding Goals for Farmland Preservation in Michigan: Targeting Resiliency, Diversity and Flexibility. A Viable Agriculture Report Prepared by the Michigan State University Land Policy Institute. Report \# 2006-1.

Archambault, S., \& Ulibarri, J. (2007): Nonmarket valuation of acequias: Stakeholder analysis. Environmental Engineering and Management, 6(6), 491-495.

Arellano, A.F., Vigil, J.J., \& Benavídez, D. (1998): Acequias del Río de las Gallinas: ¿Cómo y cuándo? Prepared for El Río de las Gallinas Acequia Association.

Arrow, K. J., Solow, R., Portney, P. R., Leamer, E. E., Radner, R., \& Schuman, H. (1993): Report of the NOAA Panel on Contingent V aluation. Federal Register, 58: 4601-14.

Bardhan, P. (1993): "Symposium on Management of Local Commons". Journal of Economic Perspectives, 7(4), 87-92

Berkes, F., \& Folke, C. (1998): Linking Social and Ecological Systems. Management Practices and Social Mechanisms for Building Resilience. Cambridge, United Kingdom: Cambridge University Press.

Bishop, R., Champ, P., \& Mullarkey, D. (1995): “Contingent Valuation”. In D. W. Bromley (Ed.), The Handbook of Environmental Economics (pp. 629-654). Cambridge, MA: Basil Blackwell. 
Boardman, A. E., Greenberg, D. H., Vining, A. I., \& Weimer, D. L. (2001): Cost Benefit Analysis: Concepts and Practice 2nd Edition. Upper Saddle River, NJ: Prentice Hall.

Boelens, R., \& Davila, G. (1998): Searching for Equity: Conceptions of Justice and Equity in Peasant Irrigation. Assen, Netherlands: Van Gorcum.

Bokum, C. (1996): "Implementing the public welfare requirement in New Mexico's water law”. Natural Resources Journal, 34; 441-473.

Bokum, C. (1996): "Implementing the public welfare requirement in New Mexico's water code". Natural Resources Journal, 36, 681.

Boyle, K.J. (2003): “Contingent Valuation in Practice". In Champ, P. A., K. J. Boyle, \& T.C. Brown (Eds.), A Primer on Nonmarket Valuation (pp. 111-169). Dordrecht, Netherlands: Kluwer.

Boyle, K. J., Johnson, F. R., McCollum, D. W., Desvousges, W. H., Dunford, R. W., \& Hudson, S. P. (1996): "Valuing public goods: Discrete versus continuous contingentvaluation responses". Land Economics, 72(3), 381-396.

Boxall, P. C., Englin, J., \& Adamowicz, W. L. (2003): "Valuing Aboriginal artifacts: a combined revealed-stated preference approach". Journal of Environmental Economics and Management, 45, 213-230.

Broadbent, C.D., Brookshire, D.S., Coursey, D.L., Ganderton, P.T., \& Tidwell, V.C. (2012): "Water markets in New Mexico". In Brookshire, D.S., Gupta, H.V., \& Matthews, O.P. (Eds.), Water Policy in New Mexico (pp.153-75). New York: Resources for the Future Press.

Brown, F. L., Nunn, S. C., Shomaker, J. W., \& Woodard, G. (1996): The Value of Water. Report to the City of Albuquerque in response to RFP-95-010-SV.

Cameron, T.A., Poe, G. L., Ethier, R. G., \& Schulze, W. D. (2002): “Alternative nonmarket value-elicitation methods: Are the underlying preferences the same?" Journal of Environmental Economics and Management, 44(3), 391-425.

Colby, B. G. (1995): "Regulation, imperfect markets, and transaction costs: The elusive quest for efficiency in water allocation". In D. Bromley (Ed.), The Handbook of Environmental Economics (4th ed) (pp. 475-502). Malden, MA: Blackwell.

DeGroot, R. S., Wilson, M. A., \& Boumans, R. M. J. (2002): “A typology for the classification, description and valuation of ecosystem functions, goods and services". Ecological Economics 41(3), 393-408.

De Groot, R., Stuip, M., Finlayson, M., \& Davidson, N. (2006): Valuing wetlands: Guidance for valuing the benefits derived from wetland ecosystem services. Ramsar Report No. 3 CBD Technical Series No. 27. Gland, Switzerland: Ramsar Convention Secretariat.

Dillman, D. A. (2000): Mail and Internet Surveys: The Tailored Design Method. New York, NY: John Wiley \& Sons.

Drake, L. (1992): The non-market value of the Swedish agricultural landscape. European Review of Agricultural Economics, 19(3), 351-364.

Evans, T., \& Lindline, J. (2004): Water quality assessment in the Gallinas watershed, Las Vegas, New Mexico. Research report, New Mexico Highlands University. Retrieved from http://wrri.nmsu.edu/research/rfp/studentgrants03/reports/evans.pdf 
Fernald, A. G., Baker, T. T., \& Guldan, S. J. (2007): "Hydrologic, riparian, and agroecosystem functions of traditional acequia irrigation systems". Journal of Sustainable Agriculture, 30(2), 147-171.

Fernald, A. G., \& Guldan, S. J. (2006): "Surface water- groundwater interactions between irrigation ditches, alluvial aquifers, and streams". Reviews in Fisheries Science, 14, 79-89.

Fleming, W., Rivera, J., Ageton, C., Jandacek, A, Marmon, J., Messenger, et al. (2001): "Transfer of development rights as an option for land preservation in a historic New Mexico community: La Cienega Valley, Santa Fe County, New Mexico". Natural Resources Journal, 41, 427-444.

Furuseth, O. J. (1987): "Public attitudes towards farmland preservation". Growth and Change, 18(3), 49-61.

Gardner, B. D. (1977): "The economics of agricultural land preservation". American Journal of Agricultural Economics, 59(5), 1027-1036.

Godoy, R., Brokaw, N., \& Wilkie, D. (1995): "The effect of income on the extraction of non-timber tropical forest products: Model, hypotheses, and preliminary findings from the Sumu Indians of Nicaragua". Human Ecology, 23(1), 29-52.

Greene, W. H. (2003): Econometric Analysis, Fifth Edition. Upper Saddle River, NJ: Prentice Hall.

Groenfeldt, D. (2005): Multifunctionality of Agricultural Water: Looking Beyond Food Production and Ecosystem Services. Prepared for the FAO/Netherlands International Conference on Water for Food and Ecosystems, The Hague, Jan. 31 - Feb. 5, 2005.

Gutzler, D.S. (2012): “Climate and drought in New Mexico”. In Brookshire, D.S., Gupta, H.V., \& Matthews, O.P. (Eds.) Waterpolicy in New Mexico (pp.56-70). New York: Resources for the Future Press.

Halstead, J. M. (1984): "Measuring the nonmarket value of Massachusetts agricultural land: A case study". Journal of the Northeastern Agricultural Economics Council, 13(1), 12-19.

Hall, G.E. (2012): “The tangled history of New Mexico water law”. In D. S. Brookshire, H. V. Gupta, \& O. P. Matthews (Eds.), Water Policy in New Mexico (pp.73-84). New York, NY: Resources for the Future Press.

Han, S.-Y., Kwak, S.-J., \& Yoo, S.-H. (2008): "Valuing environmental impacts of large dam construction in Korea: An application of choice experiments". Environmental Impact Assessment Review 28, 256-266.

Hutchins, W. A. (1928): “The community acequia, its origin and development”. Southwestern Quarterly 31(3), 261-84.

Ingram, H., \& Brown, F. L. (1998): "Commodity and community water values. experiences from the U.S. Southwest". In R. Boelens, \& G. Dávila, (Eds.), Searching for Equity: Conceptions of Justice and Equity in Peasant Irrigation. Hassen, Netherlands: Van Gorcum.

Johnson, R. D., Gisser, M., \& Werner, M. (1981): “The definition of a surface water right and transferability". Journal of Law and Economics, 24(2), 273-288.

Johnston, R. J., Opaluch, J. J., Grigalunas, T. A., \& Mazzotta, M. J. (2001): "Estimating amenity benefits of coastal farmland". Growth and Change, 32(3), 305-25.

Jorgensen, B. S., Syme, J. G., Bishop, B. J., \& Nancarrow, B. E. (1999): "Protest responses in contingent valuation". Environmental and Resource Economics, 14(1), 131-50. 
Keleher, W. A. (1929): Law of the New Mexico land grant. New Mexico Historical Review, 4(4), 350-371.

Kline, J., \& Wichelns, D. (1994): "Using public referendum data to characterize public support for purchasing development rights for farmland". Land Economics, 70(2), 223-233.

Kline, J., \& Wichelns, D. (1996a): "Measuring public preferences for the environmental amenities provided by farmland". European Review of Agricultural Economics, 23, 421-436.

Kline, J., \& Wichelns, D. (1996b): "Public preferences regarding the goals of farmland preservation programs". Land Economics, 72(4), 538-549.

Lockwood, M., Tracey, P., \&Klomp, N. (1996): "Analyzing conflict between cultural heritage and nature conservation in the Australian Alps: A CVM Approach". Journal of Environmental Planning and Management, 39 (3), 357-370.

Loomis, J. B., \& White, D. S. (1996): "Economic benefits of rare and endangered species: Summary and meta-analysis". Ecological Economics 18,197-206.

Maas, A. \& Anderson, R. L. (1978): ... and the Desert Shall Rejoice: Conflict, Growth, and Justice in Arid Environments. Cambridge, MA: MIT Press.

Maddala, G. S. (1983): Limited Dependent and Qualitative Variables in Econometrics. New York, NY. Cambridge.

Michie's annotated statutes of New Mexico. (2005): Chapter 72. Water laws. Charlottesville, VA: Lexis-Nexis.

Millennium Ecosystem Assessment (MEA) (2005): Ecosystems and Human Well-Being: Synthesis. Washington, DC: Island Press.

NASS (2002a): 2002 census of agriculture. County profile. San Miguel, New Mexico. Retrieved January, 2008, http://www.nass.usda.gov/census/census02/profiles/nm/cp35047.PDF

New Mexico Acequia Association (NMAA). (2005): Acequia Governance Handbook. Santa Fe, NM.

New Mexico Office of the State Engineer (OSE). (1991): Pecos River stream system bydrographic survey report: Gallinas River section. Volume 1 of 5. Irrigation uses tracts GR-1A.1 through GR17.104. San Miguel County. New Mexico State Engineer Office. Santa Fe, NM.

New Mexico Environment Department (NMED) (2005): Gallinas River Watershed Restoration Action Strategy. Retrieved April 11, 2008, from http://www.nmenv.state.nm.us/swqb/wps/WRAS/Gallinas_River_13060001_WRAS_M arch_2005.pdf

Nickerson, C. J., \& Lynch, L. (2001): “The effects of farmland preservation programs on farmland prices". American Journal of Agricultural Economics, 83(2), 341-351.

Nieto-Phillips, J. M. (2004): The Language of Blood: The Making of Spanish American Identity in New Mexico-1880s-1930s. Albuquerque, NM: University of New Mexico Press.

Noonan, D. (2003): "Contingent valuation and cultural resources: A meta-analytic review of the literature". Journal of Cultural Economics, 27(3-4), 159-176.

Nunn, S. C., Ben David, S., Urban, J., \& Shomaker, J. W. (1991): Expediting Changes in Water Use: Hydrologic Criteria and Market Transactions. New Mexico Water Resources Research Institute Technical Completion Report no. 225. Las Cruces, NM. New Mexico State University. 
Ortiz, M., Brown, C., Fernald, A., Baker, T. T., Creel, B., \& Guldan, S. (2007): "Land use change impacts on acequia water resources in northern New Mexico". Journal of Contemporary Water Research and Education, 137, 47-54.

Peña, D. G. (2003): “The Watershed Commonwealth of the Upper Rio Grande". In K. Boyce, \& B. G. Shelley (Eds.), Natural Assets: Democratizing Environmental Ownership (169186). Covelo, WA: Island Press.

Phillips, F. M., Hall, G. E., \& Black, M. E. (2011): Reining in the Rio Grande: People, Land, and $W$ ater. Albuquerque, NM: University of New Mexico Press.

Plantinga, A. J., \& Miller, D. J. (2001): “Agricultural land values and the value of rights to future land development". Land Economics, 77(1), 56-67.

Raheem, N. (2008): Non-market and Public Welfare Values of Common Pool Irrigation in New Mexico. Dissertation Abstracts International, A-69/09. University of New MexicoAlbuquerque.

Randall, A. (2002): "Valuing the outputs of multi-functional agriculture". European Review of Agricultural Economics, 29(3), 289-307.

Reisner, M. (1986): Cadillac desert: the American West and its disappearing water. New York: Penguin.

Rivera, J. A. (1996): The Acequias of New Mexico and the Public Welfare. Research Report \#008. Albuquerque, NM: The University of New Mexico Southwest Hispanic Research Institute.

Rivera, J. A. (1998): Acequia Culture: Water, Land \& Community in the Southwest. Albuquerque, NM: University of New Mexico Press.

Rivera, J.A. (2006): The community irrigation ditches of the upper Rio Grande: Development history and contemporary issues. Unpublished report from the 52nd International Congress of Americanistas.

Rodriguez, S. (2006): Acequia. Water Sharing, Sanctity, and Place. Santa Fe, NM: School for Advanced Research.

Rønningen, K., Flø, B. E., \& Fjeldavli, E. (2004): The Legitimacy of a Multifunctional Agriculture. Paper no 6/04, ISSN 1503-2736. Centre for Rural Research, Norwegian University of Science and Technology, 7491 Trondheim, Norway.

Rushton, M. (1999): "Methodological individualism and cultural economics". Journal of Cultural Economics, 23, 137-147.

Saavedra, P. (1987): Surface water irrigation organizations in New Mexico. Report TDDC-87-2. Santa Fe, NM. Office of the State Engineer. Retrieved from http://www.nmacequiacommission.state.nm.us/Publications/ose-acequia-rpt1987.pdf

Simmons, M. (1972): "Spanish irrigation practices in New Mexico". New Mexico Historical Review 47(2), 135-150.

Smith, K.R. (2006): "Public payments for environmental services from agriculture: Precedents and possibilities". American Journal of Agricultural Economics, 88(5), 1167-1173.

Swinton, S. M., Lupi, F., Robertson, G. P., \& Hamilton, S. K. (2007): “Ecosystem services and agriculture: Cultivating agricultural ecosystems for diverse benefits". Ecological Economics, 64(2), 245-252. 
Thomson, B.M. (2012): "Water resources in New Mexico". In Brookshire, D.S., Gupta, H.V., \& Matthews, O.P. (Eds.), Water Policy in New Mexico (pp.25-55). New York: Resources for the Future Press.

Throsby, D. (2003): "Determining the value of cultural goods: How much (or how little) does contingent valuation tell us?" Cultural Economics, 27(3-4), 275-285.

UNESCO. (2003): The Convention for the Safeguarding of Intangible Cultural Heritage. Retrieved June 24, 2014, from http://www.unesco.org/culture/ich/index.php?pg=00006

US Census. (2000): Retrieved April 22, 2005, from http://www.census.gov/prod/2001 pubs/c2kbr01-2.pdf

Venn, T. J., \& Quiggin, J. (2007): “Accommodating indigenous cultural heritage values in resource assessment: Cape York Peninsula and the Murray-Darling Basin, Australia". Ecological Economics, 61(2), 334-344.

Watkins, J. (2005): “Cultural Nationalists, Internationalists, and "Intra-nationalists": Who's Right and Whose Right?” International Journal of Cultural Property, 12, 78-94.

Wilkinson, C.F. (1992): Crossing the next meridian: Land, water, and the future of the West. Washington, D.C., \& Covelo, CA: Island Press. 